ISBN: 978-93-86878-17-5

12th PATTAYA International Conference on Chemical, Agricultural, Biological and Environmental

Sciences (PCABES-18)

Pattaya (Thailand) May 31-June 2, 2018

\title{
Influence of Doses of Mineral Fertilizers on Anatomical Structure of Vegetative Organs of Rice Varieties in Kazakhstan
}

\author{
K.N.Zhailybay ${ }^{1}$, G.Zh.Medeuova ${ }^{2}$, N.K.Nurmash ${ }^{2}$ \\ ${ }^{1}$ Kazakh State Women's Pedagogical University \\ ${ }^{2}$ Kazakh National Agrarian University \\ ${ }^{3}$ The Republic of Kazakhstan, Almaty
}

\begin{abstract}
The effect of increasing doses of mineral fertilizers on the formation and modification changes in the anatomical structures of vegetative bodies of rice under the conditions of the Kazakhstani Aral Sea region has been studied. With the application of an optimally high dose of mineral fertilizers, anatomical and morphophysiological characteristics and properties have been found that positively influence the formation of high yields: the number of small, external conducting beams increases, as well as the inner large conducting beams and their area; in the central vein of the leaves, the number of conducting beams increases, the leaf area and the number of photosynthetic mesophilic cells. This contributes to an increase in the yield of grain and its quality. Negative influence of high doses of fertilizers: small and large conductive bundles are located closer to the periphery of the stem, which leads to an expansion (to some extent) of the internal cavity of the stem. This increases (to a certain extent) the lodgingability of the rice stem.
\end{abstract}

Keywords: Rice, fertilizers, the effect of increasing doses of mineral fertilizers on the anatomical structure of the stem, leaves, rice root.

\section{Introduction}

For humans, rice is the staple food for most of the world, and it ranks second in comparison to wheat in its importance as food. [1] Rice is grown annually in the world about 672 million tons [1]. There are three main nutrients, namely: Nitrogen $(\mathrm{N})$, potassium $(\mathrm{K})$ and phosphorus $(\mathrm{P})$, necessary for a rice plant. The three main fertilizers Urea, Murie from potash (CC) and triple superphosphate (TSP) provide nitrogen, potassium and phosphorus, respectively [2]. To stimulate plant growth, fertilizers are added to the soil to provide all the necessary nutrient elements available for harvesting [3]. Together with leaching and erosion losses, fertilizers should be used to ensure the compensation of nutrients depleted from the soil by absorbing the crop [3]. For plants, inorganic fertilizers isolate nutrients into an easily soluble regime in soil solution, and these are instantly available as nutrients [4]. From the variety of rice, the state of the soil depends the consumption of fertilizer [5]. The application of nitrogen fertilizers especially in the wet season, creates serious diseases that lead to low efficiency [5]. There are four methods of requirements for fertilizers: field experiments, soil tests, plant tests and biological tests [6].

The most expensive input of fertilizers in the production of rice is nitrogen fertilizer for fertilization and irrigation [7]. The quality and yield of rice for the uneven application of nitrogen fertilizers in soils is the most important component [8]. Photosynthesis, the accumulation of biomass and the formation of spikelet that determines the yield of rice due to its role, nitrogen is the main nutrient [9]. Increased use of fertilizers, especially nitrogen fertilizers, affects a significant improvement in crop yields [10]. 


\section{Methodology of Research}

Scientific research work was carried out in 2001-2016. in the laboratory of plant physiology and the department of agro technology of the Kazakh Scientific Research Institute of Rice Farming named after I. Zhakayev and the Kazakh State Women's Teacher Training University. The experimental design and experimental work were carried out and carried out by setting up model (small-scale), field and production experiments. In the plowing layer of the soil of the Karaultubi experimental farm (Kyzylorda region, Kazakhstan) in 1968-1970. The content of humus was $1.16-1.41 \%$, and in 2001-2010, the humus content in the $0-25 \mathrm{~cm}$ layer was in the range $0.88-1.05 \%$, total nitrogen $0.083-0.093 \%$, total phosphorus $0.092-0.097 \%$. The level of mobile phosphorus is $23.6-28.4 \mathrm{mg} / \mathrm{kg}$ soil, potassium is $292-316 \mathrm{mg} / \mathrm{kg}$. Consequently, in these soils the humus content decreased by $27-35 \%$, and the nitrogen content is average, or lower than the average, and the level of potassium content is moderate. Such a phenomenon is characteristic in all soils of the rice system of the Kazakhstani Aral Sea region. The type of soil salinity is chloride-sulfate, and the level of salinity is high. The experiments were carried out on old irrigated, hydromorphic, meadow-bog soils. Agrochemical properties of these soils are given in Table 1.

TABLE I: Agrochemical characteristics of meadow-bog soils of the experimental site

\begin{tabular}{|c|c|c|c|c|c|c|}
\hline $\begin{array}{l}\text { Taken soil samples, depth, } \\
\mathrm{cm}\end{array}$ & Humus content, $\%$ & $\begin{array}{l}\text { Total } \\
\text { nitrogen, } \%\end{array}$ & $\begin{array}{l}\text { Total } \\
\text { phosphorus, } \%\end{array}$ & $\begin{array}{l}\mathrm{P}_{2} \mathrm{O} \\
\text { Movable } \\
\text { forms, } \\
\mathrm{mg} / \mathrm{kg} \\
\text { soil }_{5}\end{array}$ & $\mathrm{NH}_{4}$ & $\overline{\mathrm{NO}_{3}}$ \\
\hline \multicolumn{7}{|l|}{ 2001-2004 гг. } \\
\hline $0-20$ & 1,03 & 0,083 & 0,092 & 28,4 & 28,7 & 27,8 \\
\hline $20-40$ & 0,88 & 0,073 & 0,086 & 21,5 & 24,6 & 25,7 \\
\hline \multicolumn{7}{|l|}{ 2005-2010 гг. } \\
\hline $0-20$ & 1,05 & 0,093 & 0,097 & 23,6 & 30,4 & 27,5 \\
\hline $20-40$ & 0,83 & 0,084 & 0,085 & 20,4 & 26,3 & 25,3 \\
\hline
\end{tabular}

According to the above data, agro climatic, agro ecological and soil-ameliorative conditions are favorable for rice cultivation, however these soils are poor in nitrogen, therefore, an optimal dose of nitrogen fertilizers is required. Doses and ways of applying mineral fertilizers: 1.NOP0- control; 2.N60P90 (before sowing) + N30 (top dressing) $=\mathrm{N} 90 \mathrm{P} 90 \mathrm{~kg} /$ ha of dw .; 3.N60P90 (before sowing) + N60 (additional dressing) = N120P90 kg / ha; 4. $\mathrm{N} 60 \mathrm{P} 90+\mathrm{N} 90$ (additional fertilizer $=\mathrm{N} 150 \mathrm{P} 90 \mathrm{~kg} / \mathrm{ha} ; 5 . \mathrm{N} 60 \mathrm{P} 90$ (before sowing) $+\mathrm{N} 120$ (additional dressing) $=$ N180P90 kg / ha; 6.N60P90 (before sowing) + N90 (feeding) = N150P120 kg / ha; .N60P90 (before sowing $+\mathrm{N} 120$ (additional fertilization) $=\mathrm{N} 180 \mathrm{P} 120 \mathrm{~kg} /$ ha aa The studied varieties Marzhan, Aral 202, Aru, seeding rates - 5.6.7 million germinated seeds. the study of their anatomical structures was carried out by known methods.

\section{Results and Discussion Anatomical Structure of Stems}

The following cells are located on the transverse section of the stems (Fig. 1, Table 1): epidermis (1), small, green assimilating parenchyma (2), colorless primary parenchyma (3), structure of single-layered epidermal wall (1) mesh, small, walls thickened and saturated with silicon, top covered with a thin cuticle. In cells of the epidermis there is no stomata, there are one or two hairs. The shape of the hair is round, convex, or slightly elongated. Small, slightly elongated, densely located parenchymal (2) cells are located below the epidermis, between the cells there are narrow lumens. Further, to the bottom of the small parenchymal (2) cells there are large, basic assimilating parenchymal (3) cells, their shape is roundish, there are several elongated forms, the walls of these cells are thin, there are intercellular spaces.

In the stems there are two rows of vascular-fibrous conducting bundles. The number of beams in the stem is from 20 to 40. The sclerenchyma coating of the conducting beams merge with the sclerenchyma elements of the ring. The "outer", small vascular-fibrous conduction bundles (4) are located at a "large distance" from each other, 
and in the parenchyma located closer to the center, large fibrous vascular bundles (5) are formed that form an almost "regular circle". All conducting bundles are closed, collateral. In the center of the stem is the cavity (6), formed as a result of the death of the parenchymal cells (Figures 1,2).

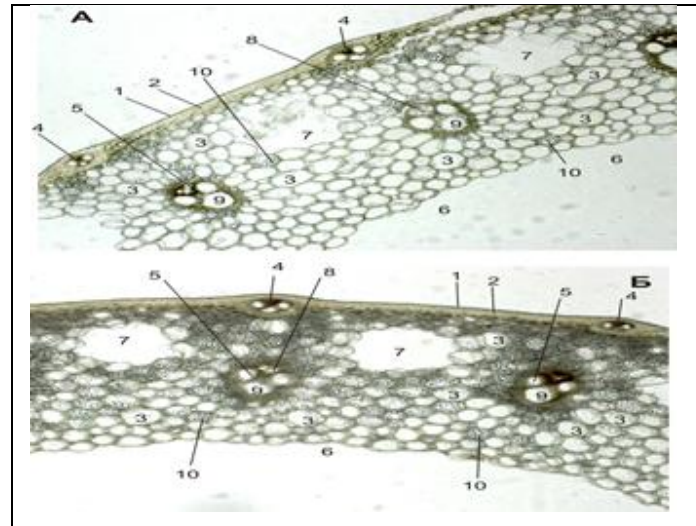

Fig. 1: The anatomical structure of the stem of the rice of the Aral 202 (A, on top of the 1st internode and B, at the bottom of the 2nd internode); Variant-seeding 5 million germinated seeds; without fertilizer (control). Designations: 1 - epidermis; 2 - small parenchymal cells; 3- basic parenchymal cells; 4- "external" conducting beams; 5- large, "internal" conducting beams; 6 - cavity inside the stem; 7-aerenheim; 8-phloem; 9 - vessels of xylem; 10 - Starch granules.

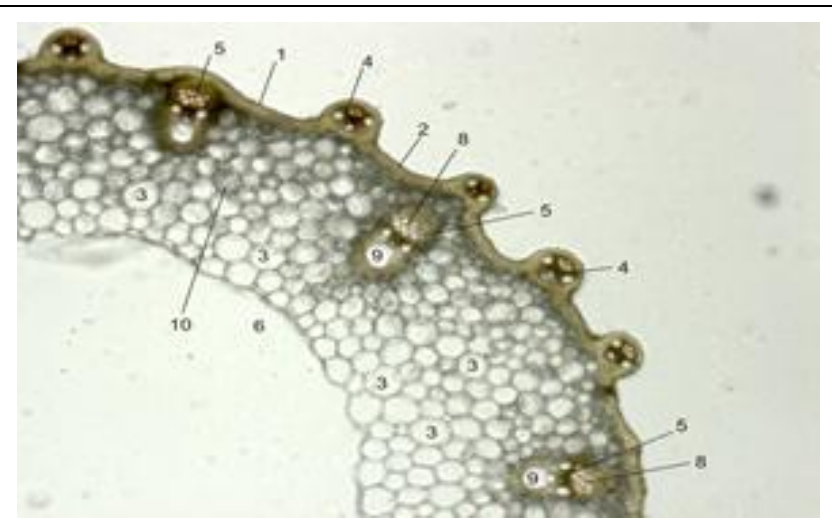

Fig. 2: Anatomical structure of the stem of Aral 202. Option-seeding 7 million seeds, applying an optimally high dose (N60P120 + N120 kg / ha ai). Notation: same as in Fig.

The composition of the conducting beams includes elements of phloem (8) and xylem (9). Xylem is 3-4, sometimes 5 vessels, among them 1-3 large-lobes, forming a short radial chain. The phloem (8) has the form of a grid, the cells of which correspond to the cross section of the sieve tubes and consist of small, "satellite" cells. Protofloema altered, located along the edges of the bundles (Fig. 1.2). Quantitative indices of the anatomical structure of the stem in the sectional view also change. Thus, the number of large conducting beams and their area, as well as the number of small, outer beams in Aral 202 are significantly higher than those of Marzhan (standard). This is one of the indicators of the superiority of the newly regionalized Aral 202 (Table 1). 
Table 1. Quantitative indices of the anatomical structure of the stem of rice cultivars depending on increasing doses of fertilizers

\begin{tabular}{|c|c|c|c|c|c|c|}
\hline \multirow[b]{2}{*}{$\begin{array}{l}\text { Varieties of } \\
\text { rice }\end{array}$} & \multicolumn{3}{|c|}{ Seeding of 5 million germinated seeds } & \multicolumn{3}{|c|}{ Seeding of 7 million germinated seeds } \\
\hline & $\begin{array}{l}\text { NOP0, } \\
\text { without } \\
\text { fertilizer } \\
\text { (control) }\end{array}$ & $\begin{array}{l}\text { N60P90+ } \\
+\mathrm{N} 60, \\
\text { average dose }\end{array}$ & $\begin{array}{l}\text { N60P120+ } \\
+\mathrm{N} 120, \quad \text { high } \\
\text { dose }\end{array}$ & $\begin{array}{l}\text { N0P0, } \\
\text { without } \\
\text { fertilizer } \\
\text { (control) }\end{array}$ & $\begin{array}{l}\text { N60P90+ } \\
+ \text { N60, } \\
\text { average dose }\end{array}$ & $\begin{array}{l}\text { N60P120+ } \\
+\mathrm{N} 120, \quad \text { high } \\
\text { dose }\end{array}$ \\
\hline \multicolumn{7}{|c|}{ Internal, large conductive bundles, pcs. } \\
\hline $\begin{array}{l}\text { Marzhan, the } \\
\text { standard }\end{array}$ & $8,7 \pm 0,33$ & $10,3 \pm 0,32$ & $16,7 \pm 0,71$ & $10,2 \pm 0,33$ & $13,0 \pm 0,55$ & $17,1 \pm 0,63$ \\
\hline Aral 202 & $12,3 \pm 0,31$ & $16,0 \pm 0,40$ & $20,0 \pm 0,60$ & $12,3 \pm 0,30$ & $16,0 \pm 0,70$ & $19,0 \pm 0,40$ \\
\hline Aru & $9,7 \pm 0,33$ & $13,6 \pm 0,37$ & $18,7 \pm 0,70$ & $10,8 \pm 0,41$ & $14,1 \pm 0,63$ & $18,2 \pm 0,51$ \\
\hline \multicolumn{7}{|c|}{ External, small conductive bundles,pcs. } \\
\hline $\begin{array}{l}\text { Marzhan, the } \\
\text { standard }\end{array}$ & $12,7 \pm 0,87$ & $14,3 \pm 0,86$ & $20,0 \pm 0,57$ & $15,8 \pm 0,52$ & $17,3 \pm 0,61$ & $21,8 \pm 0,77$ \\
\hline Aral 202 & $15,3 \pm 0,80$ & $20,0 \pm 0,70$ & $28,0 \pm 0,60$ & $17,3 \pm 0,41$ & $20,3 \pm 0,50$ & $26,7 \pm 0,61$ \\
\hline Aru & $15,7 \pm 0,87$ & $18,7 \pm 0,86$ & $21,7 \pm 0,56$ & $16,2 \pm 0,65$ & $18,5 \pm 0,66$ & $21,2 \pm 0,54$ \\
\hline \multicolumn{7}{|c|}{ Area of internal, large conducting beams, $\mu \mathrm{m} 2$} \\
\hline $\begin{array}{l}\text { Marzhan, the } \\
\text { standard }\end{array}$ & $115,7 \pm 0,6$ & $116,7 \pm 0,3$ & $138,7 \pm 0,7$ & $117,3 \pm 0,4$ & $121,4 \pm 0,5$ & $139,2 \pm 0,6$ \\
\hline Aral 202 & $129,3 \pm 0,3$ & $133,7 \pm 0,6$ & $138,0 \pm 0,6$ & $127,3 \pm 0,2$ & $135,4 \pm 0,8$ & $143,3 \pm 0,4$ \\
\hline Aru & $118,7 \pm 0,6$ & $122,7 \pm 0,3$ & $132,0 \pm 0,7$ & $118,2 \pm 0,5$ & $123,5 \pm 0,6$ & $136,5 \pm 0,6$ \\
\hline
\end{tabular}

With the increase in the seeding rate to 7 million germinating grains and the application of an optimally high fertilizer dose, small, "external" conduction beams are located on the outer side of the stem in the form of a bulging growth, which increases the stem facets. Internal, large conductive bundles were located closer to the outer wall and the inner cavity (6) of the stem widened somewhat. At the same time, the length of the stem increased. This is characteristic of the Aral grade 202, which to a certain extent increases the lodging of the stem of this variety (Fig. 1.2).

\section{Anatomical structure of leaves of varieties of rice}

On the leaves of the studied varieties of rice there are (Fig. 3): cells of the epidermal covering tissue (1), (on the lower and upper side), assimilating tissues (chlorophyllous parenchyma, or chlorenchyma), mechanical tissues and conduction beams. The epidermis (epidermis) is located on both sides of the leaf - on the lower and upper sides and consists of two types of cells (Fig. 3): the closing cells-stomata and the integumentary ones, forming unicellular simple hairs (trichomes). On the upper surface of the leaf blade stomata are larger and in rice the number of stomata is larger. Outside, the cells are covered with cuticles and have protrusions. On the upper side of the leaf between the veins are cells similar to the fans, in which the walls are thin, not having chloroplasts (Figure 3). Large contractile cells lie on the upper surface of the leaf each in an amount from 4 to 6, located fanshaped. The stomata are represented by two closing cells, separated by an intercellular-stomata slit.

Assyrilating, mesophilic, chlorophyllous tissues (3) - chlorenchyma (parenchyma) are located under the epidemic, which constitute the major part of the leaf blade (Figure 3). The structure of the parenchyma (3) is complex, loose, consists of oval or rounded polyhedral cells with chloroplasts, intercellular spaces occur. Chlorophilon parenchyma (3) is not differentiated. The mechanical tissue is represented in two cases, both by the sclerenchyma vein (4,4 A), and by the sclerenchyma coating of the conducting beams (6). The named sclerenchyma cells are polyhedral, close together, there are no spaces between the cells. Parenchymal cells (5) located on both sides, surrounding the bundles are well developed. Between the three largest vessels of the xylem (9) are the connecting sclerenchyma cells (8). In the leaves of rice, the central vein is well developed, there are veins of the first order $(\mathrm{X})$, larger and developed and of the second order (Y), which are less developed and smaller in size (Figure 3). The central vein is more convex, 6-10 conducting beams are located in it, one of them is larger. The conductive beam located on the underside of the leaf faces the mechanical (sclerenchymal) cells with the floret side, and the upper fascicles with the xylem side (Figure 3). There are two larger airborne aerughema (1) on the central vein (Fig. 4). They are surrounded by parenchymal cells (2). 


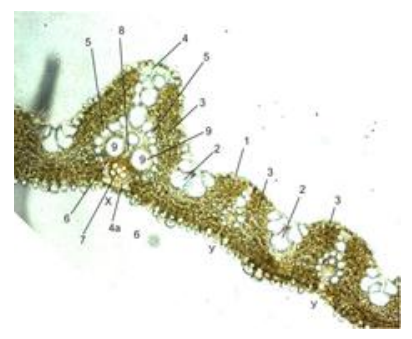

Fig.3. The anatomical structure of the second on top of the leaves of the rice Aral 202. On top of the leaves of rice when sowing 7 million seeds, without fertilizer, control; Bottom-leaves of rice when sowing 7 million seeds and applying the optimal dose of mineral fertilizers (N60P120 $+\mathrm{N} 120=\mathrm{N} 180 \mathrm{P} 120 \mathrm{~kg} / \mathrm{ha}$ ai). Notation: X-large veins of the first order; Ysmall veins of the second order; 1-epidermis; 2-contractile cells; 3-chlorophyll-based parene-chymes; 4.4A-sclerenchyma of conducting beams; 5-coated beam cells; 6-sclerenchymal cells around the vein; 7-phloem; 8-connective sclerenchyma cells; 9-vessels of xylem.

On the variant without fertilization (control) between two airborne aerogenphemic cavities (1) parenchymal cells (2) 1-2 rows, and when applying an average and optimally high dose of fertilizers, 3-5 rows (Fig. 4). Two conducting beams (3) are located on the upper and lower parts of these parenchymal cells (2), and on the sides of the cavities (1) there are 2 relatively large conducting beams (4). When applying fertilizers to rice plants in chlorophyllaceous tissues (N60P90 + N60 kg / ha) and optimally high doses (N60P120 + N120 kg / ha), surrounding the air-bearing cavities (1), 6-8 fine conducting beams (6), and there are no such conductive beams on the control (without fertilizer) (Figures 4,4A, 4B).

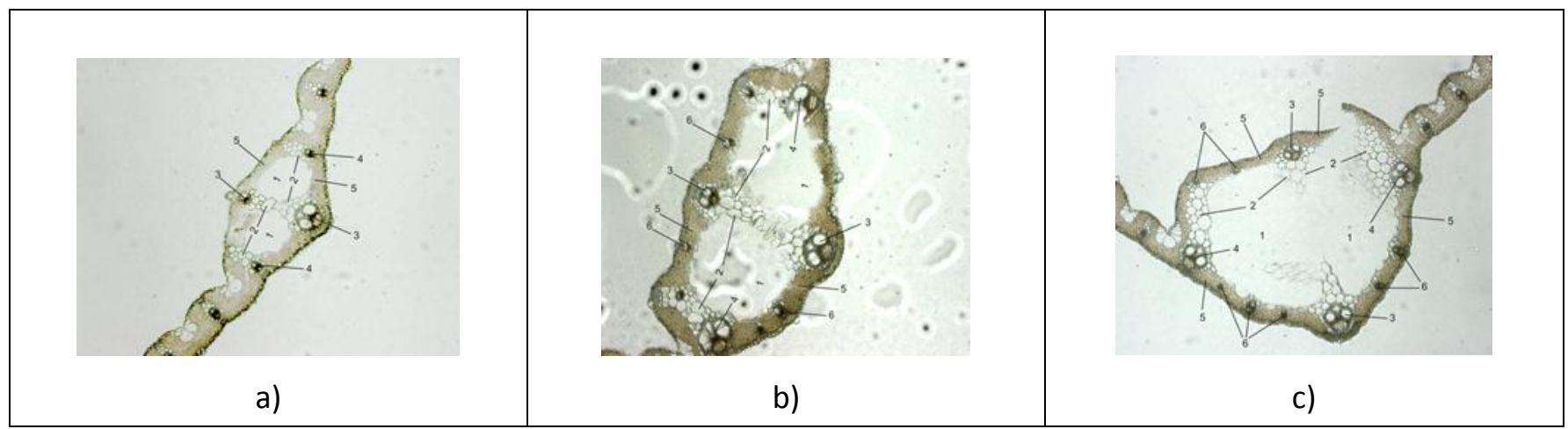

Fig.4 a).4b), 4c) Anatomical structure of the central vein of the Aral grade 202 On the left - sowing 5 million seeds, control (without fertilizer); Right - sowing 5 million seeds, applying an average dose (N60P90 + N60 kg / ha) of fertilizers; Bottomseed 7 million seeds, the application of the optimal dose (N60P120 + N120 kg / ha) fertilizer

Designations: 1- aerhenhima (air-bearing cavities); 2-parenchymal cells surrounding the aerochyma; 3conductive bundles, at both ends of the parenchymal cells, dividing the aerugens; 4-conductive bundles located along the sides of the aerenchyma; 5- parenchymal cells surrounding the aerochyma; 6 - small conduction beams located among parenchymal cells.

The leaves become longer, wider and their area increases on the thickened (seeding 7 million seeds) rice crops of Aral grade 202 and applying the optimum high dose (N60P120 + N120 kg / ha ai) fertilizers. As a result, the number of chlorophyll-bearing photosynthetic parenchyma and the number of conducting beams increase. This contributes to the synthesis of more organic substances and faster transportation to other organs, especially the poured grain in the panicle. This is evident in Fig.3.4. In rice plants with no fertilizers in parenchyma cells, starch is less transported and accumulated in the leaves, as a result of parenchymal cells are darker, since starch is not transportable, but a spare substance. With the application of an optimally high fertilizer dose, due to the 
increase in the conducting beams, the synthesized organic matter is transported more and more quickly to the panicle and other organs, which causes parenchymal cells to be more transparent, since there is no starch in them.

\section{Anatomical structure of the roots of rice varieties}

The root system of rice is pomaceous, there are two types: embryonic (basic) and nodal (lateral) roots. The main root appears from the embryo 1-3 pcs. and grows down. Then near the embryonic roots appear 4-5 nodal (lateral) roots. From the node of tillering during vegetation, new lateral roots appear in accordance with the number of lateral shoots. Depending on the level of the agrophone and the area of feeding, the nodal (lateral) roots can reach up to 300 pieces. and these roots fully provide food to the rice plants during the vegetation. Therefore, the anatomical structure of the nodal (lateral) roots was studied (Figure 5). In the transverse section of the root (Figure 5), the areas of the cortex (2) and the central cylinder (4) are distinguishable. Outside, the root is covered with the rhizoderm and epidermis (1), the cells of which are single-row, slightly elongated and have thin membranes. Then follows a layer of elongated-elongated thin-walled cells of the exoderm (5). This is followed by a sclerenchyma ring (12), whose walls are dense and consists of cellulose, providing mechanical strength of the root. The bark (2) is represented by large parenchymal (6) cells with thin walls and air-bearing cavitiesaerenchymes (3). The parenchyma is represented by large parenchymal (6) cells with thin walls. Cells of the main parenchyma (6) fill the entire space from the sclerenchyma ring (12) to the central ring (4) of the root. Between the parenchymal cortex (6) cells large elongated air-bearing cavities-aerenchymes (3) of the cortex are formed. Endoderma (7) is represented by a single layer of thin-walled rounded cells. Behind the endoderm is the layer of pericycle cells (8). Large vessels of xylem (9) on variants without fertilizer (control) are in number 4, and the vessels of metaxylem (10) are on average 16-20, next to which phloem (11) is localized (Fig.5.5A).

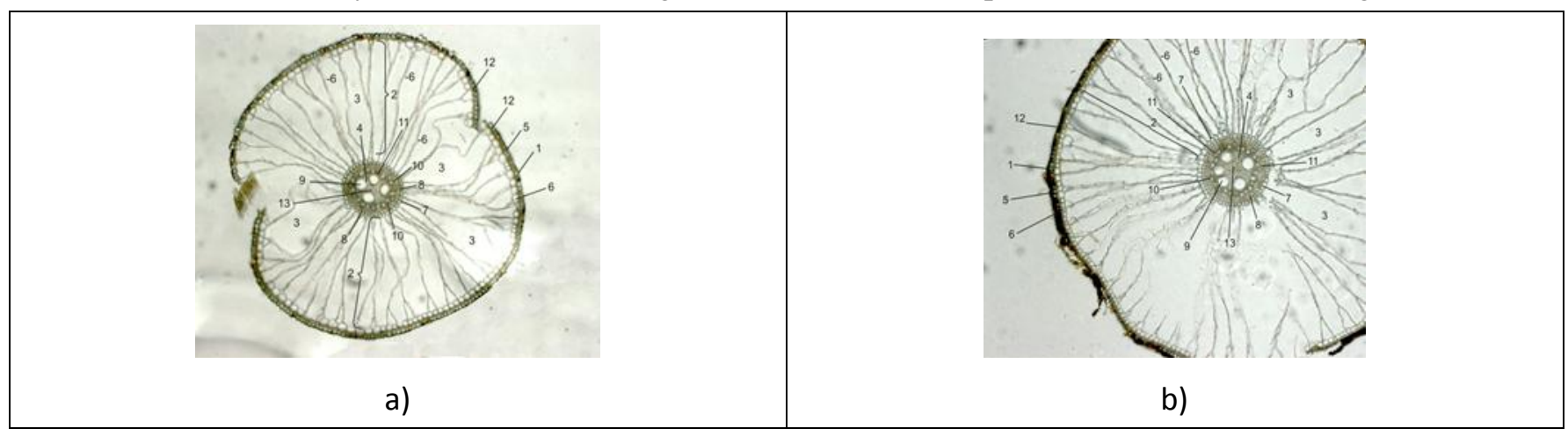

Fig. 5a).5b). Anatomical structure of the root of rice Aral 202. To the left - sowing 7 million seeds, control (without fertilizer); On the right - seeding 7 million seeds, applying the optimal high dose (N60P120 + N120 kg / ha of d.v.) fertilizers. Designations: 1-epilblem; 2-bark of the root; 3- aerhenhima; 4-central cylinder; 5-exoderm; 6-basic parenchymal tissues; 7-endoderm; 8-pericycles; 9-large xylem vessels; 10-small, metaxilemic vessels; 11-phloem; 12-sclerenchymal ring of the root cortex; 13 -sclerenchymal cells of the connective parenchyma.

With the application of an average dose (N60P90 + N60 kg / ha) of fertilizers, the 5th xylem vessel began to form, and with the application of optimally high doses $(\mathrm{N} 60 \mathrm{P} 120+\mathrm{N} 120 \mathrm{~kg} / \mathrm{ha})$ fertilizers, 5 xylem vessels were completely formed, and small meta-xylemic vessels (10) on average, 21-26 (Fig. 5A). Near the metaxilemic vessels phloem is localized (11). In the center of the cylinder is located scleralized cells of the connective parenachyma (13). With increasing doses of mineral fertilizers, the parenchyma cells are better preserved in rice roots. With increasing doses of fertilizers, the parenchymal tissues (6) of the root cortex remain larger (Fig. 5A). This apparently, to a certain extent, contributes to a greater absorption of nutrients dissolved in water and transport them through the parenchyma to the xylem vessels. 


\section{Conclusions}

With increasing doses (N60P120 + N120 kg / ha ai) fertilizers, especially top dressing, the number of outer small and inner large conducting beams increase and the sizes of internal large conducting beams increase. This facilitates the transport of more assimilates synthesized in leaves to the filling grain and to other rice organs. When the fertilizer dose is increased on the rice stalks, the small outer conduction beams are located closer to the outer side of the stem in the form of rounded outgrowths, and the inner large conduction beams are located closer to the periphery of the stem. As a result, the inner cavity of the stem widens, which makes the stem sturdy to lodging. In addition, the stem is lengthened. This is the negative effect of high doses of mineral fertilizers. For injections of medium (N60P90 + N60 kg / ha) and optimally high (N60P120 + N120 kg / ha) fertilizer doses, 6-8 conducting beams are located in the central vein of leaves, and on the variant without fertilizer (control) of such small conductive beams are not available. In the variant without fertilizer, there are 4 large xylemic vessels in the central cylinder of the rice root of Aral 202, and the metaxylemic vessels are on the average 16-20 pieces. When applying the optimal dose (N60P120 + N120 kg / ha) of fertilizers in the Aral 202, 5 large xylem vessels are fully formed, and the number of metaxylemic vessels is larger, on average 21-26 pcs.

\section{References}

[1] FAO STAT, 2011. Retrieved 28th November 2011 http://faostat.fao.org

[2] H.K.J. Ekanayake, "The Impact of Fertilizer Subsidy on Paddy Cultivation in Sri Lanka, Staff studies", Central bank of Sri lanka. 2006. pp 73.

[3] M.W. Thenabandu, "Use of fertilizers and manures in Sri Lanka", In: Science education series No 5, National Science council of Sri Lanka, Colombo, 1980.

[4] M. Siavoshi, A. Nasiri, and S.L. Laware, Effect of organic fertilizer on growth and yield components in rice (Oryza sativa L.). Journal of Agricultural science, 2011, pp 217-224.

https://doi.org/10.5539/jas.v3n3p217

[5] C.V. Hach, and N.T.H. Nam, "Response of some promising high yielding rice varieties to nitrogen fertilizer", Omonrice, Vol.14, 2006.pp.78-91.

[6] E.G.D. Priyangani, N.S. Kottearachci, D.P.S.T.G. Attanayaka and B.D. Pathinayake "Characterization of Suwandal and Heenati rice varieties for the fragrance gene using Polymerase Chain Reaction based molecular markers", Faculty of Agriculture and plantation management, Wayamba University of Sri Lanka, 2008.

[7] Fageria, N. K., V. C. Baligar and C. A. Jones. 1997. Growth and Mineral Nutrition of Field Crops. 2nd ed. Marcel Dekker, New York.

[8] Wang, Y. Y., B. Zhu, Y. Shi and C. S. Hu. 2008. Effect of nitrogen fertilization on upland rice based on pot experiments. Commun. Soil Sci. Plan 39(11-12): 1733-1749.

https://doi.org/10.1080/00103620802073743

[9] Yoshida, H., T. Horie and T. Shiraiwa. 2006. A model explaining genotypic and environmental variation of rice spikelet number per unit area measured by cross-locational experiments in Asia. Field Crops Res. 97: 337-343.Emir. J. Food Agric .Vol 28. Issue 2.2016135

[10] Cassman, K. G., A. D. Dobermann, D. Walters and H. Yang. 2003. Meeting cereal demand while protecting natural resources and improving environmental quality. Ann. Rev. Environ. Res. 28: 315-358. https://doi.org/10.1146/annurev.energy.28.040202.122858 